\title{
Jordanian Travel Agencies' Websites Assessment: Experts vs Tourists' Perceptions
}

\author{
Husam Ahmad Kokash \\ Assistant Professor, Marketing Department, CBA College, Prince Sultan University \\ P O box 66833, Riyadh 11586, Kingdom of Saudi Arabia \\ Tel: 966-1-494-8542Ｅ-mail: hkokash@psu.edu.sa
}

Received: January 2, 2012 Accepted: January 17, $2012 \quad$ Published: April 1, 2012

doi:10.5539/ijms.v4n2p80 URL: http://dx.doi.org/10.5539/ijms.v4n2p80

\begin{abstract}
By using importance-performance analysis (IPA), this paper examines the perceptions of tourists as websites users, and experts of Internet applications, of various tourism services attribute in the Jordanian travel agencies' websites. IPA is a feasible approach to the assessment of clients' satisfaction which allows for an easy and practical understanding of both the strengths and weaknesses, and for developing areas of a given service. While, IPA Analysis as a practical methodology has been used to determine customers' perceptions and satisfaction in different fields and subjects, to the best of the author knowledge, this is the first time for this methodology has been used to compare the perceptions of tourists and experts of Internet technology in order to assess the effectiveness of travel agencies websites. The main findings determined differences between tourists' perceptions of importance and experts' evaluation of Performance about JTAs websites, majorly in categories of marketing, functionality, interaction and basic information. The study also demonstrates the effectiveness of IPA model as a strategic tool at the marketers' hand, to identify priorities for areas of development and improvement by select how to increase their capacity.
\end{abstract}

Keywords: Importance-performance analysis, Internet, WWW, Travel agencies, Jordan

\section{Introduction}

Internet with its technological aspect provides several opportunities for tourism marketing in general, and for the travel agencies especially, across transforming the marketing mix, adapting it to the characteristics of the Internet and the World Wide Web technology, and by presenting a wide range of information about destinations and tourism services, in order to provide tangibility to what is intangible. (Wan, 2002; Kasavana, 2002; Sigala, 2001; Liebmann, 2000; Rushmore, 2000; Benckendorff and Black, 2000; Dewar, 2001; Adillón, \& Fransi, 2003).

Researches in tourism affirm that the web content and design are essential fields for marketing activities, since they increase the quality of products and services offered to tourists, as well as improve the destinations' image. (Perdue, 2001).

Considering a travel agency's website as a mirror that reflects the organizational commitment and efforts toward customers, we can say, the first effect which it leaves in the users' mind, does not have less importance than the overall corporate image.

Likewise, if the travel agency's website design is poorly constructed, it neither attract tourists nor satisfy their needs, which fail in capturing excellent customer value, and consequently, it will implicate a high and unnecessary cost instead of to be a strategic investment. (Iwaarden et al., 2004; Andsager \& Drzewiecka, 2002).

According to Der Merwe and Bekker (2003), the existing methods for the evaluation of the Websites' functions are not sufficient; since many of these methods currently are neither systematic nor exhaustive, this creates the need to establish a practical and comprehensive method based on the comparison of several websites in the same field of industry. In this sense, a skill can be useful for the websites analysis is the Importance-Performance (IPA), which is to a certain extent similar to the Gaps models of (SERVQUAL AND SERVPERF).

The Importance-performance analysis and in contrast to the model SERVPERF of Cronin and Taylor (1992) which consists entirely of the evaluation of the service's functions (Service Performance evaluation), it is an explanatory skill and a measurement of achievement and performance based on perceptions of the service quality. 
Also, it tries to identify the importance of several qualities criteria. In other words, the Importance-performance analysis provides a reflection on the relative value of several qualities attributes. Therefore, IPA analysis is an instrument of strategic direction, especially to direct resources to areas where the progress of the performance probably will have more significance in the clients' overall satisfaction (Miranda et al., 2010).

The main purpose of this research is to evaluate the Jordanian travel agencies' websites by using a practical method, where the current approach tries to evaluate the websites from tourists' perspectives. Similarly, by comparing the current status of the websites' implementation with what is considered by tourists, it will be possible to determine gaps distance between these two main factors.

\section{Research objectives}

The main purpose of our research aims at analyzing the Jordanian travel agencies' websites from the tourists' point of view. In this regard, we aim to achieve the following objectives:

1) Identify features of Jordanian travel agencies' websites.

2) Determine key elements and characteristics in a website of travel agency according to the tourists' perceptions.

3) Assess the Jordanian travel agencies' websites, and determine whether those sites offer what tourists want.

4) Determine if there are some missed opportunities by the Jordanian travel agencies in promoting their services online.

\section{Literature Review}

\subsection{Website Evaluation}

In many similar studies, several skills of websites analysis have been developed using methods based on personal preferences (Webb and Sayer 1998). Baggio (2003) affirms, the best way to determine the level of technology adopted by tourism organizations and their effectiveness, is to observe their Websites. Other researchers proposed that the indicators of high quality websites should incorporate some factors like: downloads speed, usability, accessibility of website, availability through affiliation, listed in search engines results, navigation and easy use, quality/quantity of the information offered, security, and visual pleasant appearance. (Bender, 1997/1998; Breitenbach and Van Dorin, 1998; Perdue, 2001; Moraleda et al, 2004).

Jung and Baker (1998) confirmed that the content is the principal factor of website's success, which helps to increase the number of visitors. Similarly, Rachman \& Buchanan (1999), asserted in their study on the tourism websites effectiveness, that the content of a website is the main factor that attracting users and generate traffic to the web, and even to let them repeat the virtual visit. Although, Tweney (1999) believes that the traffic or the number of the visitors of a website is not always an indicator of the web success.

The World Tourism Organization UNWTO (1999), has evaluated of 90 Websites of leading tour operators all over the world, it has developed a series of variables and items as an influential web content, which they affect at the level of efficiency and the quality of the same one. The UNWTO affirms that the Destination Marketing Organizations DMO's and Tour operators keep on being the principal source of information about the destination in one hand, and that they help to enrich information for tourist about destinations at the other hand. Therefore, the UNWTO confirmed the importance of the existence and the presence of the tourism organizations in general on Internet and of tour operators and travel agencies particularly.

In the same way, Clavé and Villalta (2004) studied the presence of the Coastal Spanish Mediterranean tourism destinations in Internet; their study analyzed the technical characteristics of 8 tourism destinations' websites, and they determined utmost possibilities to improve factors in the websites such as interaction and transaction. Also, the Websites of the Spanish autonomous regions were checked and evaluated in an analysis of content that demonstrated the possibilities and advantages of the Internet as a new promotional and communication channel for tourism. (Luque et al. 2004).

\subsection{The Importance-performance Analysis}

(IPA) was introduced by Martilla and James (1977) as a framework to understand the clients' satisfaction as a function of two expectations related to projected attributes, using groups or experts as a sample unites in order to create a list of the above mentioned attributes. (Martilla y James, 1977; Graf et al., 1992; Duke y Mount, 1996; Skok et al., 2001; Shaw et al., 2002; Bacon, 2003; Duke, 1996). Likewise, the simplicity, flexibility, and visual approach to the analysis, make IPA usefully support strategic decisions.

The analysis begins with the identification of the critical elements to be evaluated, then, a developed instrument will be used to gather the grades of importance and performance, and normally, the Likert scale is used to achieve 
this objective. (Martilla y James, 1977; Duke, 1996; Graf et al, 1992; Skok et al, 2001; Magal \& Levenburg, 2005; Sheih \& Wu, 2009).

Once the averages of importance and performance for elements are calculated, we typically need to assign the Performance along the axis $(\mathrm{X})$ and the importance along the axis $(\mathrm{Y})$. In this way, the coordinated point for each element they determine it set in one of four strategic sections which shape the matrix of the (IPA) analysis. (Crompton and Duray, 1985; Graf et al, 1992; Barsky and Labagh, 1992; Sheih \& Wu, 2010).

The position of the elements can be based on any number of methods, for example, mean values, average point of scale or average weight for the importance. However, the average value of elements is the most appropriate and widely used method. (Martilla and James, 1977; Crompton and Duray, 1985; Dolinsky, 1994; Graf et al., 1992; Weber, 2000; O'Neill et al., 2001). According to Skok et al. (2001), the reliability meaning of the relationship between performance and the importance have been extensively verified and confirmed.

The literature demonstrates numerous utilities of IPA analysis, since this method has been used widely to develop and evaluate the clients' satisfaction in services and marketing strategies, in many researches as those of (Martilla and James, 1977; Crompton and Duray, 1985; Sampson and Showalter, 1999).

Also, IPA has been used in operation strategies (Slack: 1994), operations system and information technologies (O'Neill et al., 2001; Skok et al. 2001), and in human resource management (Graf et al., 1992).

In addition, the Importance-performance analysis has been applied in many fields, like in the automobile industry (Martilla and James, 1977), tourism (Weber, 2000), education (Roszkowski, 2003) and in many other services sectors, especially in banking (Yeo, 2003), healthcare care services (Miranda et al., 2010) and publishing (O'Neill et al., 2001).

\section{Research Framework}

Our research is based on examining and evaluating the Jordanian travel agencies' websites through tourists' perspectives. To carry out the research objectives, we have developed two different questionnaires; each one tries to measure and evaluate different aspects related to the factors under investigation. The first questionnaire has been designed according to the studies of the World Tourism Organization UNWTO (1999; 2001). Therefore, we have determined the Jordanian travel agencies' websites, then, the Importance-performance analysis has been structured in a base of seven categories (home page, basic tourism information, complementary information, Interactivity, navigation, functionality, and marketing characteristics), and each category was formed by sub-items and characteristics of the Web (see table 1).

The evaluation of this analysis is qualitative, and it aims first of all at measuring the grade of Importance of website content according to the tourists' point of view, while the performance grade of the websites was examined and checked by using expert panel. Therefore, the above mentioned items in seven categories are the same to evaluate the importance as well as the Performance, but with only one difference, which is the scale used for the evaluation process of each of these two dimensions.

Questionnaires have been distributed in different Jordanian tourism cities (Amman \& Aqaba). Just those tourists who often visit tourism websites were involved and considered for our research as an only condition and norm to validate the case, where 153 tourists have evaluated according to their point of view the importance of each one of the eighty six aspects which forming the above mentioned seven factors of websites.

The importance of websites' attributes used importance scale based on five points Likert between one and five, where $5=$ Very Important and $1=$ Absolutely Not Important. The selected websites which form the sample in our research were checked between March 2011 and July 2011 and each website, was observed and registered separately.

With the same characteristics and different scale, the second questionnaire has been designed to evaluate the web Performance, with a scale between one and five, where $1=$ not exist extremely poor, and $5=$ excellent, which evaluates the existence and the level of Performance of each element in the Website.

The JTAs websites have been observed, and for each website, the punctuations were registered by the presence of three experts in web design and of e-business solutions. Although, the experts' panel number is relatively small, but it considers reliable and sufficient for this evaluation (Nielsen and Landauer, 1993).

The data obtained from the returned questionnaires, together with the experts' evaluation was entered into the computer program statistical package for social sciences (SPSS) version 17. The statistical analysis methods used in this study are reliability analysis, descriptive statistics, Paired sample t Test, and Simple Scatter-plot two-dimensional solution. 


\section{Results}

The reliability analysis aims at determining what set of scale items can lead to results that are highly correlated. In other words, it consists of examining the scale which leads to similar results when different persons administer it and when alternate forms of the test are used.

We have found that Cronbach Alpha of the items $=0.954$ and standardized Alpha $=0.959$ for all items of Importance, whereas Cronbrach Alpha of the items of Performance $=0.936$ and standardized Alpha $=0.946$ for all items. To make sure of this analysis, we proceeded to eliminate each one of the items of both scales (Importance-performance), the results obtained after eliminating each item one by one, where the result shows that the reliability of the scales was not improved sensitively.

The results of the Importance-Performance analysis and as can be seen in table No.1 indicates significant differences (Gaps) between both dimensions importance and performance of the Websites features and items. The longest distances between the importance and performance are clearly seen in categories like Interactivity, Communication, Home page and Marketing. Moreover, the smaller differences between the importance and performance are the characteristics of the complementary information and navigation, where we also find the highest level of performance of the websites features.

Nevertheless, there are characteristics where the grade of both importance and performance is equal, for example, in the case of the Navigation items, where they are not only have consistency, but also they consider along with the elements of the Complementary Information and in turn with the elements that more grade of importance and performance they have.

As for the home page, we find some important items which making reference to the Interaction, the easy use of the website, and navigation; like the possibility of searching the web and languages selection, where their performance does not go so far as to reach the average rate. Therefore, these elements are placed in the first section of the grid where they must be checked and treat.

The JTAs websites concentrate on the basic and necessary information. In fact, the content offered is basic and informative in nature regarding the offers, events and attractions that they promote. Also, some of JTAs usually dedicate an informative section in their websites for another type of required information that can be of a great utility for the visitors, like recommendations such as what to do in the destination, climate and suggested clothing, currency, ... etc. even some important links to other related websites of interest as Airports and Embassies, trying to present an enormous information which can be useful for their clients. However, this complementary information does not perform minor importance than the basic one in the JTAs websites, since it is not only has the tourists' consideration to be excellent, but also the JTAs understand its usefulness.

In reference to the characteristics and elements of Interactivity and Communication, there are some aspects as important as to establish an online form to order some promotional materials, trips interactive organizer, electronic brochure, and client's attention system, which they need more concentration and attention from travel agencies' side. These items of interactivity are not only important just because they refer to the communication between the organization and its potential target market, but also for their potential positive impact on the offers' promotion, by improving the image and differentiate it from its competitors.

The fact of establishing a good system that allows the effective and rapid attention to users of the web along with other characteristics, which make the website more effective to report and to solve the doubts of them, while positively affecting the travel agencies image and helps them to gain competitive advantages.

Traditionally, tourism websites carrying out these activities by establishing a section of frequent asked $\&$ answered questions FAQ, where the user for example, can submit by e-mail his question or consultation, or he can contact the travel agency via fax or telephone. But, the need to increase the interaction level of these methods, and to improve the relationship with the clients forces travel agencies toward new tools and methods, in which they can effectively attend users as rapid as possible and at any moment.

Therefore, we believe travel agencies need to adopt and develop new ways to ensure the effective attention given to their clients. Some of new utilities may be considered here, the automatic responses, call me link or (call back button) by computer - phone, and computer - computer calls based on VOIP technology, or IRC chat, which contributes in this sense to create several advantages regarding the relationship with users, but unfortunately, none of these web services is used yet by JTAs, in view of the fact that it is the case in many websites of innovative tourism organizations like in USA, Canada, Australia, France, Spain, Singapore and many other located in pioneers destinations. 
The navigation in the JTAs websites is the aspect best realized, since the design allows to carry out a high grade and level of tasks which facilitate the navigation and to get information from pages, they even offer additional services for their users as to take them to other affiliate websites and related ones in the tourism industry through links established in the website.

The functionality's items are those which have less importance and performance compared with other categories in the studied websites. This is to say, if we discard the importance of multimedia function and interactive grids, beside of presenting the website in several languages and diversification of information which relatively have a high grade of importance and performance, we find so that the importance of functionality's items does not overcome the average importance in the scale used in our study. Therefore, the majority of the above mentioned items are positioned in the third section of the (IPA Grid) titled by low priority, due to their low grade of importance and performance.

Some of the Marketing characteristics are those which have less grades of performance in the website of JTAs, and at the same time, they possess more differences in their importance. Bearing in mind that these characteristics and items are determining and criticizing the efficiency level of the websites regarding to the informative, interactive and transactional models, we can say that the majority of the studied websites are varied between informative and interactive ones, and few of them are considered operational and transactional; since we emphasize the percentage of the operational and transactional JTAs does not go so far as to form $20 \%$ of the studied websites. From this point of view, we observe that these websites usually focusing on the information offered more than on operations, leaving a big gap between what they present and what the user expects.

Please insert Figure 1 here

In summary, we indicate the importance and the performance of the Website's characteristics, where we can see clearly that the most important categories according to the tourists' evaluation were the basic information and the marketing, which possess more difference between their importance and the grade of performance. Also, we notice that navigation is the only category where the global evaluation of importance and performance is equal, and the performances of both basic and complementary information, as well as the navigation's performance are those which overcome the average grade of the scale, while the performance of the rest of categories is below the average.

\subsection{Grid of Importance - Performance of Elements and Characteristics of the Website}

The majority of the elements and characteristics are positioned in the second section of the grid (Keep up the good work), followed by the first section (Concentrate here). That is to say, there are many elements existing with high grade of importance, but not all of them have the same grade of performance, even they are not at a height of the importance confirmed by tourists; which produce a difference called (Negative GAP) between the importance and performance for each item, and therefore, it generates threats. Also, most of the items placed under the line of adjustment are positioned in the second section, and few ones of the elements which are positioned in the third and fourth sections in the grid. This means, the majority of the above mentioned elements and characteristics possess of a high grade of performance.

If we transform the items into categories, we find that the great majority of these categories fall in the field of threats with different priorities to act. On the other hand, none of the categories is positioned in the satisfactorily area (on the adjustment line or below). That is to say, if we observe the categories in the figure No. 2, with the line of adjustment horizontally, we find that the difference (Gap) between the above mentioned categories and the line is different from each category to another one.

\section{Please insert Figure 2 here}

The Marketing and the Interactivity are two categories which have more negative gaps, because their performance has a lot of differences compared with the importance, therefore, the need to act on these categories is a priority. On the other hand, we observe the gaps in the categories of basic Information, home page and the functionality also are differently far away from the adjustment line, but with a less grade than in the case of Marketing and Interactivity, while the only category that falls exactly in the line is the Navigation, where its importance and performance cross with grades of 3.75 and 3.74 respectively.

\section{Conclusions}

The achievement of activities for the websites depends on many factors as they are the target markets of a travel agency, the web skills, and especially the characteristics which the web content comprises. 
The results of the Importance-performance analysis indicate significant differences (Gaps) between the importance and the Performance in the web elements and characteristics of the JTAs. The biggest distances between the importance and the performance are seen clearly in categories as Interaction and Marketing. On the other hand, the smallest differences between the importance and the Performance were in the characteristics of Complementary Information and Navigation, where we found also the highest grade of Performance of the Web content elements.

Finally, there are three possibilities to fit categories which were distant from the adjustment line. The first one tries to move these categories horizontally to the right direction toward the line, or to attract them from the first section (A) up to the second one (section B) in the grid. The second option can be realized by moving the categories which need priority to act vertically down near the line and the third option is to shifting down the categories towards the adjustment line by inclined them $45^{\circ}$.

Although it is clear that there is relationship between the importance and the performance, here we have to observe if both are dependent or independent. (Roszkowski, 2003; Sampson and Showalter, 1999). This is the principal factor that we need to determine which of three options we must choose to fit the categories.

The first option can be realized by increasing and optimizing the performance of existing weakest elements in the web, as establish a system that allows both the booking, buying and the possibility of to provide many options for electronic payments in case of the category of marketing, to have electronic brochures, videos and photos, in the case of the communication. This will increase the performance of existing characteristics of marketing in the web, and with all we manage to reduce the negative gap between importance and performance, and to move the category horizontally toward the adjustment line.

For the second option which would try to move the categories of marketing and communication vertically, and since the dimension of Importance is dependent on the Performance, this option can be realized diminishing the grade of importance in a sense of compensating it by introducing of new elements and alternatives as marketing items in the website, this is without the need to increase the performance of existing elements, because these new items are supposed to do well and to get part of the importance weight of old characteristics.

That is to say, focus on establishing and creating new functions in the website which succeed the marketing activities; such as free e-mail address, chat and offers/destinations postal cards mails from the website, creating an interactive database in order to use it in customizing and personalizing the promotions and offers, create virtual communities, and offering personalized services to members.

Also, to dedicate a section in the website for special offers, offering promotional materials as discounts, coupons and special prices, establishing a system of reward points, and loyalty programs, or at least transfer the travel agency's website into interactive and operational portal, by offering an interactive trip organizer, connected to all the provisions affiliated in the industry.

Definitely, the third option which is a matter of moving and inclining the categories towards the adjustment line, it can be realized by performing of the first two options simultaneously. When we focusing more on revamping the performance and to improve the current characteristics along with introducing other functions in the web.

\section{References}

Adillón, M. J. G., \& Fransi, E.C. (2003). Modelos de evaluación de la calidad percibida: un análisis de fiabilidad y validez aplicado a los establecimientos virtuales. 27 Congreso Nacional de Estadística e Investigación Operativa. Lleida, 8-11 de Abril de 2003. [Online] Available: http://www.eticayempresa.com/congreso/03_3_6.pdf (May, 2011)

Andsager, J.L., and Drzewiecka J.A. (2002). DESIRABILITY OF DIFFERENCES IN DESTINATIONS. Annals of Tourism Research, Vol. 29, 2002, No. 2, pp. 401-421. http://dx.doi.org/10.1016/S0160-7383(01)00064-0

Bacon, D.R. (2003). A comparison of approaches to importance- performance analysis. International Journal of Market Research, 45, 1(2003), 55-71.

Baggio, R. (2003). A Websites Analysis of European Tourism Organizations. Anatolia: An International Journal of Tourism \& Hospitality Research, Vol. 14 (2), Winter 2003, pp. 93-106. http://dx.doi.org/10.1080/13032917.2003.9687019

Baloglu, S., \& Pekcan Y.A. (2004). The website design and Internet site marketing practices of upscale and luxury hotels in Turkey. Tourism Management, Vol. 27, (1), February 2004, 171-176. http://dx.doi.org/10.1016/j.tourman.2004.07.003

Barsky, B.J., \& Labagh, R. (1992). A strategy for customer satisfaction. Cornell Hotel and Restaurant 
Administration quarterly, 33, (1992), 32-39.

Benckendorff, P. J., \& Black, N. L. (2000). Destination marketing on the Internet. A case study of Australian Regional Tourism Authorities. The Journal of Tourism Studies, 11(1), 11-21.

Bender, D. (1997/1998). Navigation for better online marketing. HSMAI Marketing Review, 13, pp. 7-9.

Breitenbach, C., \& Van Doren, D. (1998). Value-added marketing in the digital domain: Enhancing the utility of the Internet. Journal of Consumer Marketing, 15(6), pp. 558-575. http://dx.doi.org/10.1108/07363769810241436

Buhalis, D. (1998). Strategic use of information technologies in the tourism industry. Tourism Management, Vol. 19, No. 5, pp. 409-421. http://dx.doi.org/10.1016/S0261-5177(98)00038-7

Clavé, S.A., \& Villalta, E. (2004). La presencia en Internet de los principales destinos turísticos del litoral mediterráneo español. V Congreso de Turismo y Tecnología de la Información y de la las comunicaciones. Málaga 13-15 de 2004.2 Oct. 200 Available: http://www.turismo.uma.es/turitec/turitec2004/docs/actas_turitec_pdf/1.pdf (May, 2011).

Crompton, J.L., and Duray, N.A. (1985). An investigation of the relative efficacy of four alternative approaches to importance- performance analysis. Journal of the Academy of Marketing Science, 13, 4 (Fall 1985), 69-80. http://dx.doi.org/10.1177/009207038501300405

Cronin, J.J., and Taylor, S. A. (1992). Measuring Service Quality: A Re-examination and Extension. Journal of Marketing, 56 July 1992. pp. 55-68. http://dx.doi.org/10.2307/1252296

Der Merwe, R.V., \& Bekker, J. (2003). A framework and methodology for evaluating e-commerce website. Internet Research Electronic Networking Applications and Policy, Vol. 13, Number 5, 2003. pp.330-341. http://dx.doi.org/10.1108/10662240310501612

Dewar, K. (2001). Marketing Tourism Destinations Online: strategies for the information age. Book reviews / Tourism Management, 22 (2001), 419-426.

Dolinsky, A.L. (1994). A consumer complaint framework with resulting strategies: An application to higher education. Journal of Services Marketing, 8, 3 (1994), 27-39. http://dx.doi.org/10.1108/08876049410065598

Doolin, B., Burgess, L., \& Cooper, J. (2002). Evaluating the use of the Web for tourism marketing: a case study from New Zealand. Tourism Management, 23 (2002), 557-561. http://dx.doi.org/10.1016/S0261-5177(02)00014-6

Duke, C.R., \& Mont, A.S. (1996). Rediscovering Performance-Importance Analysis of Products. The Journal of Product and Brand Management (5:2), 1996, pp. 43-54. http://dx.doi.org/10.1108/10610429610119441

Fernández Barcala, M. (2000). Validación de SERVQUAL como instrumento de medida de la calidad de servicio bancario. Revista Europea de Dirección y Economía de la Empresa. Vol. 9, NO. 1, pp. 57-70.

Genestre, A., and Herbig, P. (1997). OF CUSTOMER SERVICE, PRODUCT PARAMETERS, AND SERVICE QUALITY: SATISFIERS AND DISSATISFIERS. Academy of Marketing Studies Journal, Volume 1, Number 2, 1997 pp. 45-62.

Graf, L.A., Hemmasi, M., and Nielsen, W. (1992). Importance-Satisfaction Analysis: A Diagnostic Tool for Organizational Change. Leadership and Organization Development Journal (13:6), 1992, pp. 8-12. http://dx.doi.org/10.1108/01437739210021857

Grandona, E.E., \& Pearson, J.M. (2004). Electronic commerce adoption: an empirical study of small and medium US businesses. Information \& Management, 42 (2004), 197-216. http://dx.doi.org/10.1016/j.im.2003.12.010

Ho, J. (1997). Evaluating the World Wide Web: A global study of commercial sites. Journal of Computer Mediated Communication, 3(1), pp. 1-30. http://dx.doi.org/10.1111/j.1083-6101.1997.tb00066.x

Iwaarden, J.V., Wiele, T.V.D., Ball, L., \& Millen, R. (2004). Perceptions about the quality of web sites: a survey amongst students at Northeastern University and Erasmus University. Information \& Management, 41, pp. 947-959. http://dx.doi.org/10.1016/j.im.2003.10.002

Jung, H., \& Baker, M. (1998). Assessing the marketing effectiveness of the World Wide Web in national tourism offices. In Buhalis, D., Tjoa, A., Jafari, J. (Eds.), Information and communication technologies in tourism 1998. (pp. 93-102) New York Springer-Wien.

Kasavana, M. L. (2002). EMarketing: restaurant websites that Click. Journal of Hospitality and Leisure Marketing, 9(3/4), pp. 161-178. http://dx.doi.org/10.1300/J150v09n03_11 
Liebmann, L. (2000). Help for building sticky web sites: Simple, inexpensive site enhancements can increase visits, retention, and conversion. Information Week. (815). [Online] Available: http://www.informationweek.com/815/webapps.htm

Luque P. D., Plaza A. G, \& Herrero J. L. C. (2004). Promoción Turística de las Comunidades Autónomas en Internet. V Congreso "Turismo y Tecnologías de la Información y las Comunicaciones" TuriTec 2004. Málaga 13-15 de Oct. 2004.2 Available: http://www.turismo.uma.es/turitec/turitec2004/docs/actas_turitec_pdf/3.pdf (June, 2011).

Magal, S., \& Levenburg, N. (2005). Using Importance-Performance Analysis to Evaluate E-Business Strategies among Small Businesses. Proceedings of the 38th Hawaii International Conference on System Sciences. Volume 7. http://dx.doi.org/10.1109/HICSS.2005.661

Martilla, J.A., \& James, J.C. (1977). Importance-Performance Analysis. Journal of Marketing (41:1), 1977, pp. 77-79.

Miranda, F. J., Chamorro, A., Murillo, L.R., \& Vega, J. (2010). An Importance-Performance Analysis of Primary Health Care Services: Managers vs. Patients Perceptions. J. Service Science \& Management, 2010, (3), 227-234. http://dx.doi.org/10.4236/jssm.2010.32028

Moraleda, L.F., Domecq, C.F., \& Baltasar, M. (2004). Modelo de Análisis de Páginas Web de Cadenas Hoteleras: El Caso de España y Portugal. V Congreso "Turismo y Tecnologías de la Información y las Comunicaciones" TuriTec 2004. [Online] Available: http://www.turismo.uma.es/turitec/turitec2004/docs/actas_turitec_pdf/2.pdf (June, 2011).

Nielsen, J., and Landauer, T. K. (1993). A mathematical model of the finding of usability problems. Proceedings of ACM INTERCHI'93 Conference (Amsterdam, The Netherlands, 24-29 April 1993), pp. 206-213.

O'Neill, M., Wright, C., and Fitz, F. (2001). Quality evaluation in on-line service environments: An application of the importance-performance measurement technique. Managing Service Quality, 11, (6), 402-417. http://dx.doi.org/10.1108/EUM0000000006519

Organización Mundial de Turismo (OMT). (1999). Promoción de Destinos Turísticos en el Ciberespacio, Retos del Marketing Electrónico. Consejo Empresarial de la OMT. Madrid.

Organización Mundial de Turismo (OMT). (2001). Comercio Electrónico y Turismo: Guía Práctica para Destinos y Empresas. Consejo Empresarial de la OMT. Madrid.

Parasuraman, A., Berry, L.L., \& Zeithaml, V. A. (1991). Refinement and Reassessment of the Servqual Scale. Journal of Retailing, 67(4), winter, 420-450. http://dx.doi.org/10.1111/j.1438-8677.2010.00335.x

Perdue, R. R. (2001). Internet site evaluations: the influence of behavioural experience existing images and selected website Characteristics. Journal of Travel \& Tourism Marketing, 11(2/3), pp. 21-38. http://dx.doi.org/10.1300/J073v11n02_02

Rachman, Z., \& Buchanan, J. (1999). Effective tourism Web sites, Part 1: Literature review and features survey. [Online] Available: http://www.mngt.waikato.ac.nz/depts/mnss/john/1999-12TourismWeb.pdf (Jan. 28, 2011).

Rachman, Z., \& Richins, H. (1997). The status of New Zealand tour operator Web sites. Journal of Tourism Studies, 8, (2), pp. 62-77.

Roszkowski, M.J. (2003). The nature of the importance- satisfaction relationship in ratings: Evidence from the normative data of the Noel-Levitz student satisfaction inventory. Journal of Consumer Satisfaction, Dissatisfaction and Complaining Behavior, 16, (2003), pp.211-221.

Rushmore, S. (2000). Internet 101: introduction to building a hotel Website. HOTELS MAGAZINE: The magazine of the worldwide hotel industry. 34, (4), pp. 44.

Sampson, S.E., \& Showalter, M.J. (1999). The performance- importance response function: Observations and implications. The Services Industries Journal, 19, 3 (July 1999), 1-25. http://dx.doi.org/10.1080/02642069900000027

Shaw, N.C., DeLone, W.H., \& Niederman, F. (2002). Sources of Dissatisfaction in End-User Support: An Empirical Study. Database for Advances in Information Systems (33:2), spring 2002, pp. 41-56. http://dx.doi.org/10.1145/513264.513272 
Sheih, J.I., \& Wu, H. H. (2010). Applying information-based methods in importance-performance analysis when the information of importance is unavailable. Qual Quant (2010). Published Online: 13 March, 2010. http://dx.doi.org/10.1007/s11135-010-9312-1

Sheih, J.I., \& Wu, H. H. (2009). Applying Importance-Performance Analysis to compare the changes of a convenient store. Qual Quant (2009) 43: pp. 391-400. http://dx.doi.org/10.1007/s11135-007-9111-5

Sigala, M. (2001). Modeling e-marketing strategies: Internet presence and exploitation of Greek hotels. Journal of Hospitality and Tourism Marketing, 11(2/3), pp. 83-97. http://dx.odi.org/10.1300/J073v11n02_05

Skok, W., Kophamel, A., \& Richardson, I. (2001). Diagnosing Information Systems Success: Importance-Performance Grids in the Health Club Industry. Information \& Management (38), 2001, pp. 409-419. http://dx.odi.org/10.1108/17410390910932795

Slack, N. (1994). The importance-performance matrix as a determinant of improvement priority. International Journal of Operations \& Production Management, 14, 5 (1994), 59-76. http://dx.odi.org/10.1108/01443579410056803

Tweney, D. (1999). Measuring Internet success: You shouldn’t rely on traffic alone. Infoworld, Vol. 11, (2), pp. 58.

Wan, C. S. (2002). The web sites of international tourist hotels and tour wholesalers in Taiwan. Tourism Management, 23, pp.155-160. http://dx.doi.org/10.1016/S0261-5177(01)00048-6

Webb, B., \& Sayer, R. (1998). Benchmarking small companies on the Internet. Long Range Planning. Vol. 31, No. 6, December 1998, pp. 815-827(13). http://dx.doi.org/10.1016/S0024-6301(98)80018-6

Weber, K. (2000). Meeting planners' perceptions of hotel-chain practices and benefits: An importance-performance analysis. Cornall Hotel and Restaurant Administration quarterly, 41, 4 (August 2000), 32-38. http://dx.doi.org/10.1177/001088040004100412

Yeo, A.Y.C. (2003). Examining a Singapore bank's competitive superiority using importance-performance analysis. Journal of American Academy of Business, 3, 1/2 (September 2003), 155-161. 
Table 1. Differences between Importance \& Performance in Items \& Categories of JTAs Websites

\begin{tabular}{|c|c|c|c|c|c|c|c|c|}
\hline \multicolumn{2}{|r|}{ Home page } & \multirow{2}{*}{$\frac{\text { Importance }}{2.5}$} & \multirow{2}{*}{$\begin{array}{c}\text { Performance } \\
3.4\end{array}$} & \multirow{2}{*}{$\begin{array}{c}\text { Gap } \\
\text { Differnce= } \\
\text { P-I } \\
0.9 \\
\end{array}$} & \multirow{2}{*}{$\begin{array}{c}\begin{array}{c}\text { Difference } \\
\%\end{array} \\
18 \% \\
\end{array}$} & \multirow{2}{*}{$\frac{\text { Part }}{\mathrm{D}}$} & \multirow{2}{*}{$\begin{array}{c}\begin{array}{c}(t) \\
\text { Value }\end{array} \\
6.556 \\
\end{array}$} & \multirow{2}{*}{$\frac{\text { Sig. }}{0.096}$} \\
\hline IP 1 & Logo & & & & & & & \\
\hline IP2 & Destination description & 4 & 3.9 & -0.1 & $-2 \%$ & $\mathrm{~B}$ & 79 & $\mathbf{0 . 0 0 8}$ \\
\hline IP 3 & Destination Photos & 4.2 & 4 & -0.2 & $-4 \%$ & $\mathrm{~B}$ & 41 & 0.016 \\
\hline IP 4 & Flash Introduction & 2.3 & 2 & -0.3 & $-6 \%$ & $\mathrm{C}$ & 14.333 & 0.044 \\
\hline IP 5 & Dynamic photo-text & 2.2 & 2.6 & 0.4 & $8 \%$ & $\mathrm{C}$ & 12 & 0.053 \\
\hline IP 6 & Internal links & 3.9 & 4.3 & 0.4 & $8 \%$ & $\mathrm{~B}$ & 20.5 & $\mathbf{0 . 0 3 1}$ \\
\hline IP 7 & Languages & 4.2 & 2.5 & -1.7 & $-34 \%$ & A & 3.941 & 0.158 \\
\hline IP 8 & Search option by words & 4.2 & 2.5 & -1.7 & $-34 \%$ & A & 3.941 & 0.158 \\
\hline IP 9 & Directory search option & 3.7 & 1.9 & -1.8 & $-36 \%$ & $\mathrm{~A}$ & 3.111 & 0.198 \\
\hline IP 10 & Number of visitors & 1.5 & 1.2 & -0.3 & $-6 \%$ & $\mathrm{C}$ & 9 & 0.070 \\
\hline IP 11 & Contact Information & 3.9 & 3.7 & -0.2 & $-4 \%$ & $\mathrm{~B}$ & 38 & $\mathbf{0 . 0 1 7}$ \\
\hline IP 12 & Actualization date & 3.7 & 1.3 & -2.4 & $-48 \%$ & A & 2.083 & 0.285 \\
\hline IP 13 & Local time & 2.8 & 1.8 & -1 & $-20 \%$ & $\mathrm{C}$ & 4.6 & 0.136 \\
\hline IP 13 & Registration & 1.8 & 2.2 & 0.4 & $8 \%$ & $\mathrm{C}$ & 10 & 0.063 \\
\hline & Basic Information & Importance & Performance & $\begin{array}{c}\text { Gap } \\
\text { Differnce= } \\
\text { P-I }\end{array}$ & $\begin{array}{c}\text { Difference } \\
\% \\
\end{array}$ & Part & $\begin{array}{c}(t) \\
\text { Value }\end{array}$ & Sig. \\
\hline IP 14 & Specific destination activities & 4.4 & 4 & -0.4 & $-8 \%$ & $\mathrm{~B}$ & 21 & $\mathbf{0 . 0 3 0}$ \\
\hline IP 15 & $\begin{array}{c}\text { Tourism intermediary's } \\
\text { information } \\
\text { (Affiliate agencies, tour } \\
\text { operators) } \\
\end{array}$ & 3.6 & 3.2 & -0.4 & $-8 \%$ & $\mathrm{~B}$ & 17 & $\mathbf{0 . 0 3 7}$ \\
\hline IP 16 & $\begin{array}{c}\text { Restaurants and gastronomy } \\
\text { information }\end{array}$ & 4 & 2.8 & -1.2 & $-24 \%$ & A & 5.667 & 0.111 \\
\hline IP 17 & Museums information & 3.9 & 2.9 & -1 & $-20 \%$ & A & 6.8 & 0.093 \\
\hline IP 18 & Rent car, other services & 3.9 & 2.7 & -1.2 & $-24 \%$ & $\mathrm{~A}$ & 5.5 & 0.114 \\
\hline IP 19 & $\begin{array}{l}\text { Hospitality and hotels } \\
\text { information } \\
\end{array}$ & 4.7 & 4 & -0.7 & $-14 \%$ & $\mathrm{~B}$ & 12.429 & 0.051 \\
\hline IP 20 & Events & 4.2 & 3.5 & -0.7 & $-14 \%$ & $\mathrm{~B}$ & 11 & 0.058 \\
\hline IP 21 & Attractions & 4.5 & 4.6 & 0.1 & $2 \%$ & $\mathrm{~B}$ & 91 & $\mathbf{0 . 0 0 7}$ \\
\hline \multicolumn{2}{|c|}{ Complementary information } & Importance & Performance & $\begin{array}{c}\text { Gap } \\
\text { Differnce= } \\
\text { P-I }\end{array}$ & $\begin{array}{c}\text { Difference } \\
\% \\
\end{array}$ & Part & $\begin{array}{c}(t) \\
\text { Value }\end{array}$ & Sig. \\
\hline IP 22 & Climate and Geography & 4 & 4 & 0 & $0 \%$ & $\mathrm{~B}$ & & \\
\hline IP 23 & Clothes & 3.8 & 3.5 & -0.3 & $-6 \%$ & $\mathrm{~B}$ & 24.333 & 0.026 \\
\hline IP 24 & $\begin{array}{l}\text { Exchange and currency } \\
\text { converter }\end{array}$ & 3.9 & 3.6 & -0.3 & $-6 \%$ & $\mathrm{~B}$ & 25 & 0.025 \\
\hline IP 25 & Commercial time & 3 & 3.4 & 0.4 & $8 \%$ & $\mathrm{~B}$ & 16 & 0.040 \\
\hline IP 26 & $\begin{array}{l}\text { How to get there, how to } \\
\text { arrive (destination) }\end{array}$ & 4.4 & 3.7 & -0.7 & $-14 \%$ & $\mathrm{~B}$ & 11.571 & 0.055 \\
\hline IP 27 & Transportation & 3.7 & 3.5 & -0.2 & $-4 \%$ & $\mathrm{~B}$ & 36 & 0.018 \\
\hline IP 28 & Telecommunication & 3.3 & 3.3 & 0 & $0 \%$ & $\mathrm{~B}$ & 1 & 1 \\
\hline IP 29 & Traditions and culture & 3.9 & 3.4 & -0.5 & $-10 \%$ & $\mathrm{~B}$ & 14.6 & $\mathbf{0 . 0 4 4}$ \\
\hline IP 30 & outdoor activities & 4 & 3.1 & -0.9 & $-18 \%$ & $\mathrm{~B}$ & 7.889 & 0.080 \\
\hline IP 31 & $\begin{array}{c}\text { Links to useful Websites, } \\
\text { airport, embassies... }\end{array}$ & 3.2 & 3 & -0.2 & $-4 \%$ & A & 31 & 0.021 \\
\hline
\end{tabular}


Table 1. Continued

\begin{tabular}{|c|c|c|c|c|c|c|c|c|}
\hline \multicolumn{2}{|c|}{ Communications and interactivity } & \multirow{2}{*}{$\frac{\text { Importance }}{3}$} & \multirow{2}{*}{$\begin{array}{c}\text { Performance } \\
1.9 \\
\end{array}$} & \multirow{2}{*}{$\begin{array}{c}\text { Gap } \\
\text { Differnce }= \\
\text { P-I } \\
-1.1 \\
\end{array}$} & \multirow{2}{*}{$\begin{array}{c}\text { Difference } \\
\%\end{array}$} & \multirow{2}{*}{$\frac{\text { Part }}{\mathrm{A}}$} & \multirow{2}{*}{$\begin{array}{c}(\mathbf{t}) \\
\text { Value } \\
4.455 \\
\end{array}$} & \multirow{2}{*}{$\begin{array}{c}\text { Sig. } \\
0.141\end{array}$} \\
\hline IP 32 & e-mail list & & & & & & & \\
\hline IP 33 & e-mail link & 3.7 & 4 & 0.3 & $6 \%$ & $\mathrm{~B}$ & 25.667 & $\mathbf{0 . 0 2 5}$ \\
\hline IP 34 & $\begin{array}{c}\text { Telephone numbers, P.O. } \\
\text { box, location }\end{array}$ & 3.9 & 3.8 & -0.1 & $-2 \%$ & $\mathrm{~B}$ & 77 & $\mathbf{0 . 0 0 8}$ \\
\hline IP 35 & Fax number & 3.2 & 3.7 & 0.5 & $10 \%$ & $\mathrm{~B}$ & 13.8 & 0.046 \\
\hline IP 36 & $\begin{array}{l}\text { Customer service, free } \\
\text { telephone } \\
\text { number for client attention }\end{array}$ & 3.8 & 1.5 & -2.3 & $-46 \%$ & A & 2.304 & 0.261 \\
\hline IP 37 & Chat & 1.9 & 1 & -0.9 & $-18 \%$ & $\mathrm{C}$ & 3.222 & 0.192 \\
\hline IP 38 & $\begin{array}{l}\text { Visitors annotations, } \\
\text { comments and } \\
\text { observations } \\
\end{array}$ & 2.4 & 2 & -0.4 & $-8 \%$ & $\mathrm{C}$ & 11 & $\mathbf{0 . 0 5 8}$ \\
\hline IP 39 & $\begin{array}{l}\text { Online brochure request } \\
\text { application }\end{array}$ & 3.5 & 1.9 & -1.6 & $-32 \%$ & $\mathrm{~A}$ & 3.375 & 0.183 \\
\hline IP 40 & guest book & 2 & 1.6 & -0.4 & $-8 \%$ & $\mathrm{C}$ & 9 & 0.070 \\
\hline IP 41 & Events calendar & 3.9 & 3.4 & -0.5 & $-10 \%$ & $\mathrm{~B}$ & 14.6 & 0.044 \\
\hline IP 42 & $\begin{array}{l}\text { Registration and inscription } \\
\text { on the site }\end{array}$ & 2.1 & 2.2 & 0.1 & $2 \%$ & $\mathrm{C}$ & 43 & 0.015 \\
\hline IP 43 & Online destination's catalogue & 4 & 3.5 & -0.5 & $-10 \%$ & $\mathrm{~B}$ & 15 & 0.042 \\
\hline IP 44 & $\begin{array}{l}\text { electronic Destination's } \\
\text { catalogue }\end{array}$ & 3.9 & 2.3 & -1.6 & $-32 \%$ & A & 3.875 & 0.161 \\
\hline IP 45 & A Virtual visit & 3.4 & 1.8 & -1.6 & $-32 \%$ & A & 3.25 & 0.190 \\
\hline IP 46 & Interactive Travel organizer & 3.9 & 2.2 & -1.7 & $-34 \%$ & A & 3.588 & 0.173 \\
\hline & Navigation & Importance & Performance & $\begin{array}{c}\text { Gap } \\
\text { Differnce }= \\
\text { P-I } \\
\end{array}$ & $\begin{array}{c}\text { Difference } \\
\% \\
\end{array}$ & Part & $\begin{array}{c}(\mathrm{t}) \\
\text { Value } \\
\end{array}$ & Sig. \\
\hline IP 47 & Database Search Option & 4.4 & 2.7 & -1.7 & $-34 \%$ & A & 4.176 & 0.150 \\
\hline IP 48 & Internet Search Option & 2.9 & 1.2 & -1.7 & $-34 \%$ & $\mathrm{C}$ & 2.412 & 0.250 \\
\hline IP 49 & $\begin{array}{l}\text { List of Internal links on the } \\
\text { home page }\end{array}$ & 3.9 & 4.7 & 0.8 & $16 \%$ & $\mathrm{~B}$ & 10.75 & 0.059 \\
\hline IP 50 & $\begin{array}{c}\text { Content links in pages of the } \\
\text { website }\end{array}$ & 3.8 & 4.8 & 1 & $20 \%$ & B & 8.6 & 0.074 \\
\hline IP 51 & $\begin{array}{c}\text { Link to the home page in each } \\
\text { page of the website }\end{array}$ & 3.6 & 4.9 & 1.3 & $26 \%$ & $\mathrm{~B}$ & 6.538 & 0.097 \\
\hline IP 52 & $\begin{array}{l}\text { Links to other sites which } \\
\text { provide complete details } \\
\text { about the destination }\end{array}$ & 4.2 & 3.7 & -0.5 & $-10 \%$ & $\mathrm{~B}$ & 15.8 & 0.040 \\
\hline IP 53 & links to other relational sites & 3.7 & 3.9 & 0.2 & $4 \%$ & $\mathrm{~B}$ & 38 & 0.017 \\
\hline IP 54 & Site map & 2.8 & 2.7 & -0.1 & $-2 \%$ & $\mathrm{C}$ & 55 & 0.012 \\
\hline IP 55 & Ease of use and to get access & 4.6 & 4.5 & -0.1 & $-2 \%$ & $\mathrm{~B}$ & 91 & 0.007 \\
\hline IP 56 & $\begin{array}{l}\text { Domain name Related with } \\
\text { the destination }\end{array}$ & 3.5 & 4.1 & 0.6 & $12 \%$ & $\mathrm{~B}$ & 12.667 & 0.050 \\
\hline
\end{tabular}


Table 1. Continued

\begin{tabular}{|c|c|c|c|c|c|c|c|c|}
\hline \multicolumn{2}{|r|}{ FUNCTIONALITY } & \multirow{2}{*}{ Importance } & \multirow{2}{*}{$\begin{array}{c}\text { Performance } \\
2.5\end{array}$} & \multirow{2}{*}{$\begin{array}{c}\text { Gap } \\
\text { Differnce }= \\
\text { P-I } \\
-1.7\end{array}$} & \multirow{2}{*}{$\begin{array}{c}\text { Difference } \\
\%\end{array}$} & \multirow{2}{*}{$\frac{\text { Part }}{\mathrm{A}}$} & \multirow{2}{*}{$\begin{array}{c}\begin{array}{c}(\mathbf{t}) \\
\text { Value }\end{array} \\
3.941 \\
\end{array}$} & \multirow{2}{*}{$\frac{\text { Sig. }}{0.158}$} \\
\hline IP 57 & Languages & & & & & & & \\
\hline IP 58 & Actualization & 3.6 & 1.4 & -2.2 & $-44 \%$ & $\mathrm{~A}$ & 2.273 & 0.264 \\
\hline IP 59 & What's new & 4 & 3.4 & -0.6 & $-12 \%$ & $\mathrm{~B}$ & 12.333 & 0.052 \\
\hline IP 60 & Hits number & 1.6 & 1.6 & 0 & $0 \%$ & $\mathrm{C}$ & / & / \\
\hline IP 61 & Website design information & 1.4 & 2 & 0.6 & $12 \%$ & $\mathrm{C}$ & 5.667 & 0.111 \\
\hline IP 62 & Website usage statistics & 1.5 & 1.2 & -0.3 & $-6 \%$ & $\mathrm{C}$ & 9 & 0.070 \\
\hline IP 63 & Download option & 2.8 & 2.3 & -0.5 & $-10 \%$ & $\mathrm{C}$ & 10.2 & 0.062 \\
\hline IP 64 & Flash animation & 2.1 & 1.7 & -0.4 & $-8 \%$ & $\mathrm{C}$ & 9.5 & 0.067 \\
\hline IP 65 & Back ground's images & 2.8 & 3.7 & 0.9 & $18 \%$ & $\mathrm{D}$ & 7.222 & 0.088 \\
\hline IP 66 & back ground in Colors & 2.5 & 3.4 & 0.9 & $18 \%$ & $\mathrm{D}$ & 6.556 & 0.096 \\
\hline IP 67 & Interactive maps & 3.5 & 3.1 & -0.4 & $-8 \%$ & $\mathrm{~B}$ & 16.5 & 0.039 \\
\hline IP 68 & Multimedia & 3.4 & 1.6 & -1.8 & $-36 \%$ & A & 2.778 & 0.220 \\
\hline IP 69 & $\begin{array}{l}\text { Variety and diversification of } \\
\text { information }\end{array}$ & 4.5 & 4.1 & -0.4 & $-8 \%$ & $\mathrm{~B}$ & 21.5 & $\mathbf{0 . 0 3 0}$ \\
\hline & MARKETING & Importance & Performance & $\begin{array}{c}\text { Gap } \\
\text { Differnce= } \\
\text { P-I }\end{array}$ & $\begin{array}{c}\text { Difference } \\
\% \\
\end{array}$ & Part & $\begin{array}{c}(t) \\
\text { Value }\end{array}$ & Sig. \\
\hline IP 70 & Logo \& slogan & 2.6 & 3.3 & 0.7 & $14 \%$ & $\mathrm{D}$ & 8.429 & 0.075 \\
\hline IP 71 & Offers variety & 4 & 4.3 & 0.3 & $6 \%$ & $\mathrm{~B}$ & 27.667 & 0.023 \\
\hline IP 72 & Destinations' photography & 4.4 & 4 & -0.4 & $-8 \%$ & $\mathrm{~B}$ & 21 & $\mathbf{0 . 0 3 0}$ \\
\hline IP 73 & Destinations' Promotion & 3.9 & 3.7 & -0.2 & $-4 \%$ & $\mathrm{~B}$ & 38 & $\mathbf{0 . 0 1 7}$ \\
\hline IP 74 & $\begin{array}{l}\text { General information about the } \\
\text { offer }\end{array}$ & 4.3 & 4.6 & 0.3 & $6 \%$ & $\mathrm{~B}$ & 29.667 & 0.021 \\
\hline IP 75 & $\begin{array}{l}\text { Complete and details } \\
\text { information about the offer }\end{array}$ & 4.5 & 4 & -0.5 & $-10 \%$ & $\mathrm{~B}$ & 17 & $\mathbf{0 . 0 3 7}$ \\
\hline IP 76 & Hotels guide information & 4.7 & 3.7 & -1 & $-20 \%$ & $\mathrm{~B}$ & 8.4 & 0.075 \\
\hline IP 77 & $\begin{array}{c}\text { Airlines and service providers } \\
\text { information } \\
\end{array}$ & 3.9 & 2.9 & -1 & $-20 \%$ & A & 6.8 & 0.093 \\
\hline IP 78 & Utilities & 4.1 & 4 & -0.1 & $-2 \%$ & $\mathrm{~B}$ & 81 & 0.008 \\
\hline IP 79 & Prices information & 4.7 & 1.8 & -2.9 & $-58 \%$ & A & 2.241 & 0.267 \\
\hline IP 80 & Online booking & 4.1 & 1.9 & -2.2 & $-44 \%$ & A & 2.727 & 0.224 \\
\hline IP 81 & e-mail reservation & 3.8 & 2.3 & -1.5 & $-30 \%$ & $\mathrm{~A}$ & 4.067 & 0.154 \\
\hline IP 82 & Online order and buy & 3.9 & 2 & -1.9 & $-38 \%$ & A & 3.105 & 0.198 \\
\hline IP 83 & Electronic payment & 3.9 & 1.9 & -2 & $-40 \%$ & A & 2.9 & 0.211 \\
\hline IP 84 & Special offers & 4.5 & 1.7 & -2.8 & $-56 \%$ & A & 2.214 & 0.270 \\
\hline IP 85 & Online questionnaire & 2 & 1.3 & -0.7 & $-14 \%$ & $\mathrm{C}$ & 4.714 & 0.133 \\
\hline IP 86 & $\begin{array}{l}\text { Discount's coupons and } \\
\text { incentive programs }\end{array}$ & 4.1 & 1.4 & -2.7 & $-54 \%$ & A & 2.037 & 0.291 \\
\hline
\end{tabular}




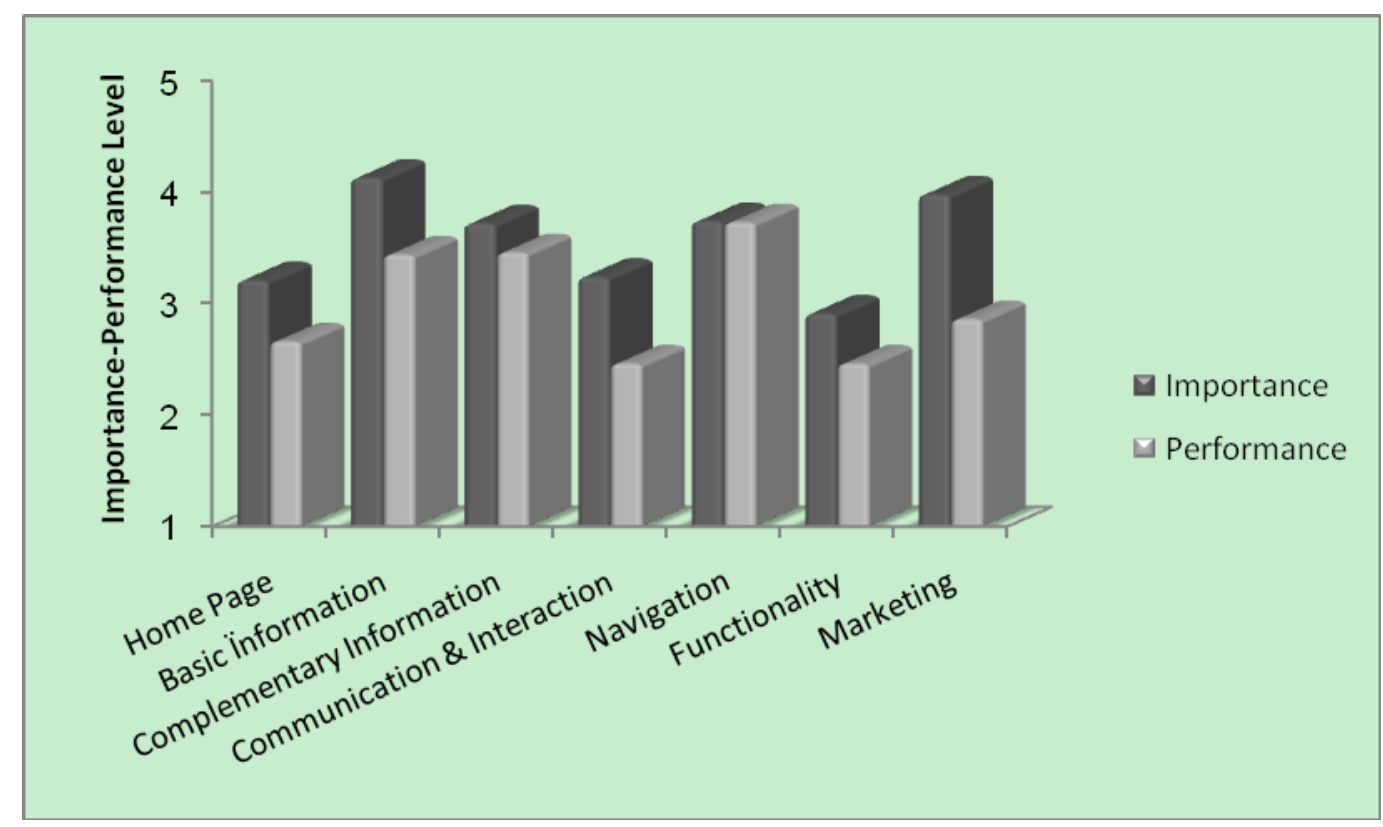

Figure 1. Differences between Importance-Performance Categories of JTAs Websites

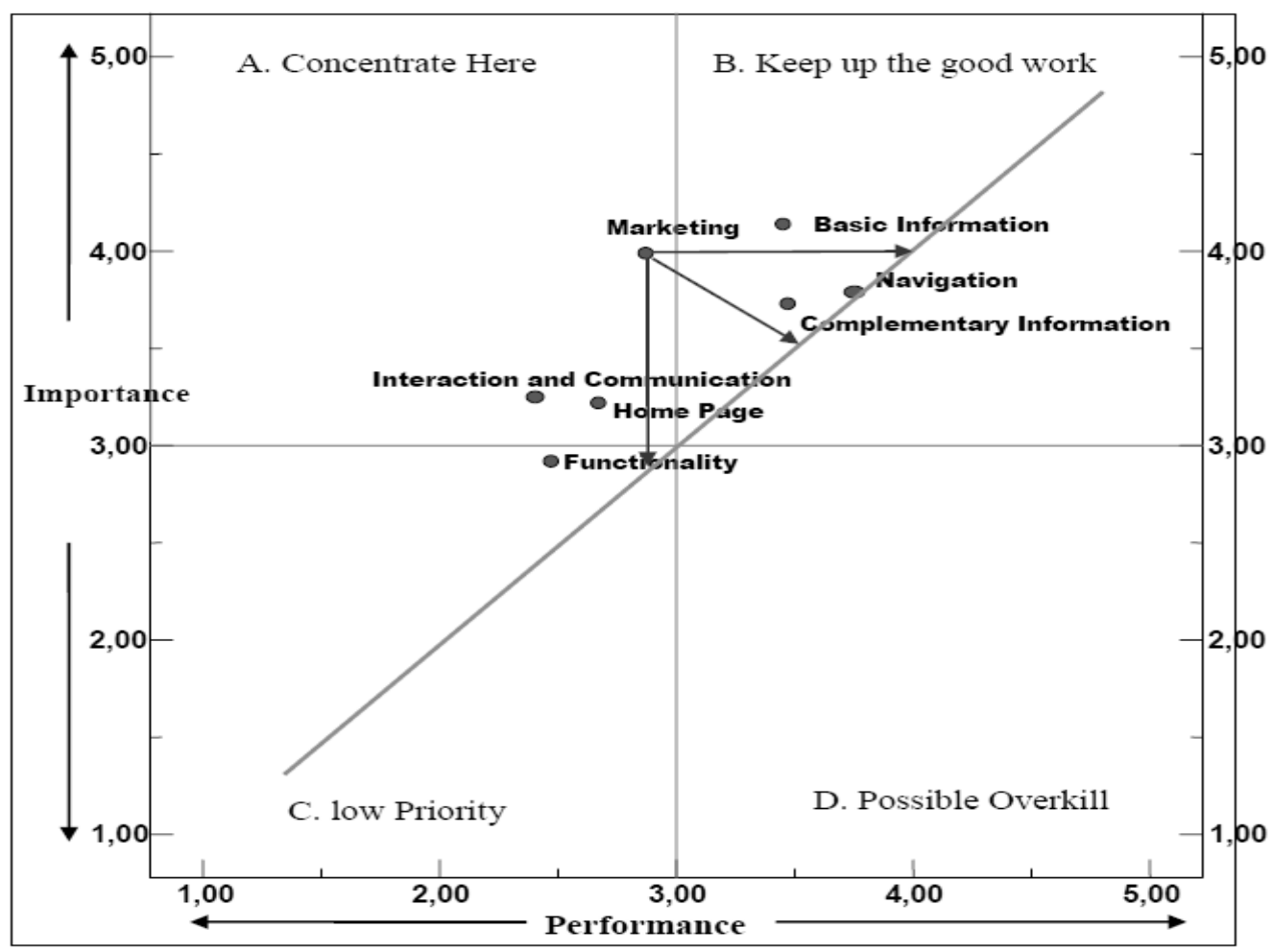

Figure 2. Importance - Performance Grid of JTAs Websites Content Categories 